\title{
Beyond the Conflict and Weak Civil Society; Stories from Ukraine: Cases of Grassroots Initiatives for Sustainable Development
}

\author{
Oksana Udovyk ${ }^{1}$ \\ Canadian Institute of Ukrainian Studies, University of Alberta
}

\begin{abstract}
This study explores the diversity of grassroots initiatives (GIs) for sustainable development that are emerging in post-EuroMaidan Ukraine. It first focuses on an overview of different theories on civil society and trends in Ukrainian civil society development. Eight cases of GIs are selected to represent different pillars of sustainability work done by the initiatives (economic, social, environmental, and political-institutional). These cases question the arguments behind the weak and pseudo-plenipotentiary vision of civil society in Ukraine, and demonstrate mechanisms of sustainable development suggested by analyzed GIs. In general, this study challenges the myth of a weak civil society in Ukraine, opens up a broader discussion on the meaning and role of civil society, and provides new ideas for building a sustainable society.
\end{abstract}

Keywords: civil and uncivil society, EuroMaidan, trust, NGO, state, Ukraine.

\section{INTRODUCTION}

$\mathrm{A}$

fter the collapse of communism, civil society in Eastern Europe was expected to become one of the key players in the process of postSoviet countries' transformation (Gatskova and Gatskov, "Third Sector in Ukraine"). However, this was not the case in reality, and civic engagement in this region was a low-frequency phenomenon in comparison to the situation in Western Europe (Bernhagen and Marsh; Howard; Kostelka).

The low degree of positive change with respect to civil society in Eastern Europe was usually explained by several factors. First of all, a number of researchers identified an unsupportive state and a difficult macroeconomic situation as unfavourable conditions for the development

\footnotetext{
${ }^{1}$ I acknowledge valuable help in reviewing this article by Serhii Cipko and Bohdan Harasymiw, both affiliated with the Canadian Institute of Ukrainian Studies, University of Alberta, as well as helpful suggestions by two anonymous reviewers. I am grateful to Bohdan Hawrylyshyn from the World Academy of Art and Science for stimulating discussions and to Canadian Institute of Ukrainian Studies for making this research possible.
} 
of civil society (Ogryzko and Pishchikova; Gatskova and Gatskov, "Third Sector in Ukraine"; Pytlik). At the same time, the majority of scholars looked for an explanation in the passiveness of former Soviet Union citizens. They even used the specific sarcastic term "Homo Sovieticus" to characterize the socio-cultural type of the average person in the Soviet Union as having a lack of initiative and a penchant to avoid taking personal responsibility (Levada and Golov).

Yet, in recent decades the actions of ordinary citizens have challenged the notion of weak civil societies in the region. Scholars have started to argue that the contemporary blossom of civic activities in the region might represent a new phase in the development of post-Socialist civil societies (Ekman et al.; Jacobsson; Sava). At the same time, sceptics of such ideas contend that despite powerful demonstrations of disappointment with the authoritarian practices of the political elites during, for example, EuroMaidan, the so-called Revolution of Dignity in Ukraine, the recent activation in civil society is still pseudo-plenipotentiary (Cleary).

This study explores these two different lines of argument (strong and weak/pseudo-plenipotentiary civil society) by analyzing empirical examples of dynamic activities of civil organizations in recent years in Ukraine. Instead of the traditional focus on registered NGOs' activities, this study will focus on nontypical forms of civic engagement and collective actions such as grassroots initiatives for sustainable development. ${ }^{2}$

Grassroots initiatives (henceforth, GIs) for sustainable development, are usually analyzed in sustainability-related publications. Such publications analyze a wide variety of initiatives, such as community gardens and organic food organizations, consumer co-operatives, local recycling projects, eco-housing, time banking, and community currencies (e.g., Seyfang and Longhurst). They examine GIs that deal with social exclusion (Williams et al.), that develop localized economies and improve resilience (Castells et al.), that stimulate sustainable consumption and production (Pearson et al.), and as innovative practices (Seyfang and Smith; Smith et al.). However, there have been very few examinations of GI as forms of civil society development (Kingsley and Townsend).

At the same time, civil society studies very rarely look at GIs. Jacobsson argues that these types of local and often small-scale forms of civil

\footnotetext{
2 Seyfang and Smith define grassroots initiatives (GIs) for sustainable development as: "innovative networks of activists and organisations that lead bottom-up solutions for sustainable development; solutions that respond to the local situation and the interests and values of the communities involved. In contrast to the greening of mainstream business, grassroots initiatives tend to operate in civil society arenas and involve committed activists who experiment with social innovations as well as using greener technologies and techniques" (585).
} 
activations can easily escape the attention of researchers who usually focus on formally organized NGOs or mass mobilization processes like EuroMaidan.

Altogether these practices make the contribution of GIs to civil society development "invisible" to researchers. Polanska suggests that the "invisibility" in such cases (those that do not fit NGO and/or "protestevent-analysis" approaches for civil society studies) could explain some of the reasons behind the creation of myths of weak civil societies in postSocialist settings, as described by Howard, and also account for inconsistencies in current visions of civil society definitions, actors, and roles. Thus, by lifting and analyzing a diverse range of GI in Ukraine, this study contributes to a broader theoretical discussion of civil actions in the country as well as of civil society development in general.

\section{BACKGROUND}

\subsection{Civil ANd UnCIVIL SOCIETIES AND THEIR FunCTIONS}

While civil society has been given a number of different definitions (e.g., D'Alisa et al.; Fukuyama; Gatskova and Gatskov, The Weakness of Civil Society in Ukraine; Howard; Newton; Putnam), there is still an ongoing discussion about what it is and what are its functions. Despite differences in definitions, it is almost impossible to find recent research publications on civil society without referring to Robert Putnam. He views civil society as a people's network that by endowments of social capital and horizontal practices can guarantee economic growth and connect people and state. Civil society in this view has a clear economic and political function (Fukuyama).

Therefore, building civil society was seen to be vital for developing capitalism and democracy in Eastern Europe (Jacobsson 274). For some authors, civil society-building in the region was an essential element of a broader neoliberal, so-called "transition economy" project (Załęski). Many NGOs that today are in place in Eastern European countries were introduced and sponsored from abroad, in order to promote this "transition" (Jacobsson 274). Through such actions, civil society in Eastern Europe was expected to develop into a "third sector" (Jacobsson 275). This approach, usually promoted by aid agencies, examined the "third sector" as a bridge between citizens and state (Chandhoke).

In What Was Socialism, and What Comes Next?, Katherine Verdery highlights that definitions of "civil society" can be blurred and mixed with ideological ideas. It can be, for example, a symbol of construction of the "Western" identity in Eastern Europe (Verdery 20). At the same time, it can 
also be connected to nation identity building and coupled to state sovereignty, as proposed in Putin's vision of civil society (see Hemment). Verdery, thus encourages others to be more critical of what "civil society" may actually mean. In this line of argument, Newton showed that the role of civil society is more complex than a common vision, e.g., developing trust between society and politics. For example, there is evidence that "social trust between citizens is not at all closely related to political trust between citizens and political leaders" (Newton 201). Furthermore, Whittington shows that distrust of government can be a citizen's legitimate decision and not a sign of a weak society.

Following Putnam's views, some civil activities are seen as "civil" while others can be framed as "uncivil" (Kopecký and Mudde 2-5). In such a dichotomy, some actors, such as NGOs, are seen as legitimate representatives of civil society while other forms of activism are not (Jacobsson 274). Delegitimized organizations can be conservative, nonconventional, or radical groups. But even these are subject to continuous change in the civil society arena (D'Alisa et al. 214). Something that is viewed as radical today may be considered completely mainstream tomorrow. Ideas as well as ideologies are continuously recreated and hegemonic paradigms can be changed (Gramsci).

Recent studies emphasize that civil society is an open arena that unites different values, objectives, and approaches (Jacobsson). That means that civil society combines groups that can resist the governmentality project $\grave{a}$ la Foucault and this notion goes beyond bridging people and state ideas of civil society function (D'Alisa et al. 214). ${ }^{3}$ This area of research on civil society is in its initial stage and thus needs further clarification. What is clear is that the focus on "civil" actors in society (e.g., NGOs) and on their function of bridging or developing trust between state and people might oversimplify the assessment.

According to Edwards and Foley, civil society's aims and functions are closely tied to the context for which they are shaped. The authors even developed the concept of "many civil societies" to exemplify the diversity of empirical examples of civil society actors, roles, and functions (Edwards and Foley). For example, they show that there is a big difference between civil societies in the 1970s and the 1980s in Latin America and Western Europe. The difference was not only in the ways they were working but also in the issues they were concerned with as well as the roles and responsibilities they had identified (Edwards and Foley 125).

3 D'Alisa and others go even further, deconstructing ideas behind civil society function in economic growth, giving examples of groups' unwillingness to be ruled by growth ideas. However, this aspect is beyond the purpose of this article. 
Nevertheless, social mobilizations in Eastern Europe are still analyzed using indicators such as the number of registered NGOs or membership in officially registered organizations (Petrova and Tarrow; Jacobsson), or the level of concern with issues of governance and policy-making (Cleary). These models and frameworks narrow the focus of the examination and can lead to different types of inadequacy of scientific interpretation (Jacobsson 221, 275). Instead of such a top-down analysis of civil society (official numbers or connection with governmental structures), Petrova and Tarrow have measured horizontal ties inside the civil society itself. They have shown that in-depth investigation of civil initiatives characteristics can tell more about civil society than, for example, numbers of registered NGOs (Petrova and Tarrow).

Thus, this study aims to fill a gap in in-depth knowledge about the practical examples/case studies of untypical forms of civil engagement in Ukraine. Instead of traditional survey-based analysis, or focus on registered NGOs/membership in registered organizations and analysis of the ways organizations are influencing the state, this article provides an empirical qualitative description of dynamic activities in the grassroots initiatives for sustainable development in Ukraine. By doing so, it contributes to a wider theoretical discussion of the definition of civil society and collective actors in post-Socialist societies.

\subsection{CiVIL SOCIETY IN UKRAINE}

Civil society in Ukraine has undergone numerous changes over the past decades: from Soviet times to Ukrainian independence and finally to recent developments. All of these stages left their marks on civil society forms and characteristics. The state-controlled associational life during Soviet times created very limited incentives to develop civil society organization, and fostered a strong level of avoidance and a low level of trust of any type of civil organization among citizens (Levada and Golov; Shiller et al.; Ljubownikow et al.).

The situation changed with Ukrainian independence. The number of registered civil organizations, for example, has increased significantly (Iedynyi reiestr hromads'kykh formuvan'). However, the same low level of active participation prevails (Gorobets). Representative sociological surveys, for example, confirmed the very low level of citizen participation (Gatskova and Gatskov, The Weakness of Civil Society in Ukraine) and the USAID NGO Sustainability Index also reported low results for Ukraine since independence ("The 2015 CSO Sustainability Index"). Overall weak NGOized civil society that was usually associated with foreign donor support became the main topic of discussion among civil society publications in the 
1990s and the early 2000s (Howard; Gatskova and Gatskov, The Weakness of Civil Society in Ukraine; Gorobets). Thus, despite the growth of its formal structures (e.g., number of registered organizations), civil society did not increase its activity in the first decades of Ukrainian independence.

It is not surprising that the population's level of trust of NGOs was very low; for example -2\% in 2012 according to the OMNIBUS survey ("Dumky ta pohliady naselennia Ukrainy"). Another survey conducted by the Razumkov Center also showed that the level of trust never exceeded 10\% in first decades of independence. The maximum value was $7.9 \%$ in February 2005, after the Orange Revolution ("Sotsiolohichne opytuvannia"). Thus, Pytlik concluded that support for civil society organizations in Ukraine was usually lower than distrust of them (250).

Yet, at the end of 2013, Ukrainian society was able to display an extraordinary level of mobilization, self-organization, and solidarity during EuroMaidan (Puglisi; Ogryzko and Pishchikova; Bohdanova). After this event, tens of thousands of people formed political organizations and civic initiatives, and volunteered for and donated to different kinds of social projects (Ogryzko and Pishchikova 6). According to the survey by GfK Ukraine, held in November 2014, nearly a quarter of all Ukrainians (23\%) have experience in volunteering, $62 \%$ recognize the importance of volunteers in political change, $85 \%$ believe that volunteering helps to promote peace, and $81 \%$ think volunteerism is a required component of a developed civil society ("Volonters'kyi rukh v Ukraini").

Impressive trends are also observed regarding level of trust in recent years. A poll shows that citizens of Ukraine most trusted volunteers $(+67 \%)$ followed by civil organizations $(+13 \%)$ among all public and power institutions. This is compared to the general level of mistrust of courts ($67 \%)$, the prosecutor's office $(-67 \%)$, police $(-57 \%)$, the government ($62 \%$ ), and the president (-33\%) ("Komu bil'she doviriaiut' ukraintsi") (see Table 1). 
Table 1. Level of Trust in Governmental and Civic Organizations (2010-15). Modified from "Komu bil'she doviriaiut' ukraintsi" by Fond Demokratychni initsiatyvy

201020112012201320142015

$\begin{array}{lcccccc}\text { President of Ukraine } & 22 & 12 & 43 & 27 & 5 & 33 \\ \text { Parliament } & 22 & 35 & 61 & 54 & 26 & 63 \\ \text { Government of Ukraine } & 1 & 28 & 49 & 36.5 & 18 & 56 \\ \text { Police } & 37 & 33 & 47 & 48 & 58 & 57 \\ \text { Local Government } & * & 10 & 5 & 4 & 15 & 22 \\ \text { Courts } & 45 & 37 & 56 & 52 & 72 & 67 \\ \text { NGOs } & 9 & * & 2 & 2 & 9 & 13 \\ \text { Volunteers } & * & * & * & * & * & \mathbf{4 4}\end{array}$

*There were no similar questions that year.

The level of civil participation has also increased. A more recent study by GfK showed that $44 \%$ of the adult population took part in at least one civil initiative in the last 12 months and $23 \%$ of the population can be called "potential activists" - those who did not take part in any initiative but would like to ("Citizen's Awareness and Engagement of Civil Society). The results are even higher for youth, where 54\% of the young people took part in civil initiatives ("Molod' Ukrainy 2015"). These results look even more impressive in comparison to 2013 , when only $8 \%$ of adults were "active" ("Komu bil'she doviriaiut' ukraintsi").

Thus, while the government of the country is going through a cascade of different reforms, elections, decision changes, and struggles to deal with an armed conflict in the eastern part of the country, something different is going on at the citizens' level-both the number of civil organizations and initiatives and the participation and trust in them is increasing tremendously.

At the same time, there are different views on this phenomenon among scholars. The first is an optimistic one (based on the observations mentioned above), challenging the weak civil society "myth" (Jacobsson; Ekman et al.; Ogryzko and Pishchikova; Pytlik) (see Table 2). Another view argues for the persistence of weak civil society ideas (Cleary; Thematic Report; Palyvoda; “Europe and Eurasia Civil Society 2015"). 
The latter view uses several arguments to support weak civil society ideas. Palyvoda, for example, showed that out of the 76,575 CSOs and 14,729 charitable foundations in Ukraine, only 4000 of them are active (10). A study of registered NGOs by the OSCE shows the same shortcomings. The OSCE report argues that some NGOs that traditionally worked with HIV switched to helping people involved in the conflict in the eastern part of the country. This means that some vulnerable individuals in society (e.g., those suffering from HIV/AIDS) are left with less support (Thematic Report 6).

Cleary adds volunteers' movements to her civil society study, in addition to traditional NGO types of service. She observes that "a growing number of citizens, acting as individuals rather than as members of organizations, have sought to take matters into their own hands" (Cleary 19). At the same time, she argues that these individual actions are not organized and thus they cannot be seen to contribute to a strong and organized civil society (19). Moreover, she does not find evidence of a new civil society effectively influencing the power structure in Ukraine. She argues that civil society does not appear to trust the government, while the government is suspicious of civil organizations and volunteers (Cleary 17). She thus asks, "if civil society is not able to bridge the gap between the people and the government [,] then what is it doing?" (Cleary 17). She shows that society is using the "wrong" functions to fulfil the responsibility of the state or to help the state, something that Caldwell also noted about Russian society. Cleary gives an example of one volunteer who is improving the government's strategic communications as her contribution to the war effort. "She could not fight, but she could still make a difference," comments Cleary (19). Thus, she concludes that civil society in Ukraine just seems to be strong and it neither builds bridges between people and the state nor establishes trust among them and thus is pseudo-plenipotentiary (see Table 2).

Table 2. Main Arguments Behind Strong and Pseudo-Plenipotentiary Civil Society in Ukraine

\section{Strong}

Increased number of registered and nonregistered civil organizations/initiatives

Increased civil participation among adults and youth

Increased volunteering experience among adults and youth

Increased level of trust of NGOs and volunteers

\section{Pseudo-plenipotentiary}

"Wrong" role in civil society (e.g., Cleary 17)

Lack of trust of the state institutions

Lack of organization

Mainly individual efforts 
By analyzing the cases of grassroots sustainability organizations in Ukraine, I will try to address these points of critique and analyze whether we see a strong or weak (pseudo-plenipotentiary) civil society in Ukraine.

\section{METHODOLOGICAL FRAMEWORK}

\subsection{FRAMEWORK OF THE ANALYSIS}

The list of GIs for sustainable development was created through an online search from December 2014 to December 2015. I was looking for new civil establishments that followed the main criteria of GIs described by Seyfang and Smith (592), that is, the establishment is:

- $\quad$ based on the social economy (rather than the market economy);

- focused on social and institutional (rather than technological) innovation;

- driven by social need and ideological commitment (rather than profitseeking);

- supported by alternative values and culture (rather than market regulation and subsidies);

- comprised of diverse organizational forms, such as co-operatives, voluntary associations, and informal community groups (rather than firms); and

- reliant on grant funding, volunteer labour, mutual exchange, and only limited commercial activity (rather than principally on commercial income).

The collection of information about nonregistered GIs is difficult, since there is no single official or unofficial database that lists these initiatives. Thus, social media webpages as well as social forums, relevant events and meetings, combined with snowball sampling using recommendations from contacted initiatives, were utilized to create a list of initiatives. This approach provided an increasing sample size. It allowed the identification of over one hundred different GIs.

The next part of the research was categorizing each GI. This study uses four categories of sustainable development based on the four-pillar model of sustainability (social, economic, environmental, and politicalinstitutional). The four-pillar model was chosen instead of the traditional three-pillar model (social, economic, and environmental) because the latter is seen to underestimate something of fundamental importance. As highlighted by Burford and others, there have been several attempts to 
define this missing aspect as a fourth pillar of sustainability. Some authors defined it as a political-institutional pillar (e.g., Pfahl).

Political-institutional aspects of sustainability are, for example, covered in the indicator system developed by the Commission on Sustainable Development (CSD) in order to assess the implementation of Agenda 21 (Pfahl 85), as well as being mentioned in Gro Harlem Brundtland's report for the World Commission on Environment and Development (Report of the World Commission). In addition to the initial Agenda 21 context, the use of the political-institutional dimension as the fourth pillar of sustainability has started to gain acceptance within international organizations. For example, the System of Environmental and Economic Accounting (SEEA) refers directly to "a fourth-institutional-pillar" ("Sustainable Development Indicators). The United Nations Division for Sustainable Development also incorporates political-institutional indicators into its framework of sustainable development indicators (Indicators of Sustainable Development).

The four-pillar model provides a good framework for the analysis of the diversity of GIs in Ukraine. Hence, the diversity of the initiatives that emerged in Ukraine will be placed in social, economic, environmental, and political-institutional categories (see Figure 1). This classification allows for the selection of eight cases-initiatives (two for each category of sustainability) to exemplify sustainability work done by GIs in Ukraine.

\section{Figure 1. The Four-Pillar Model of Sustainability}

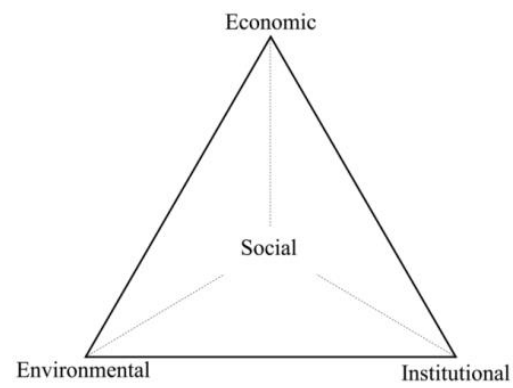

Semi-structured interviews with open-ended questions allowed indepth analyses of the cases. ${ }^{4}$ Twenty-four interviews were conducted from December 2015 to July 2016. Respondents were organizers of and participants in the analyzed GIs. The selection of respondents was based on

\footnotetext{
${ }^{4}$ Interviewees were assured of their anonymity.
} 
the idea of presenting both organizers' and participants' points of view. ${ }^{5}$ Interviews with the participants from eight cases enabled the discovery of information (such as interviewees' levels of trust or personal visions of the role of civil society), which would not be possible to obtain through written materials, e.g., surveys. This type of information is necessary for a more complete picture of civil society development in Ukraine. Questions were centred on the main points of difference between a strong civil society and a pseudo-plenipotentiary society in Ukraine (role of GIs, level of trust, organization structure, and number of people involved; see Table 2).

\subsection{CASE DESCRIPTIONS}

EuroMaidan SOS is probably the most well-known grassroots initiative in Ukraine (@EuroMaidanSOS). It emerged as a response to the violent actions of the authorities to disperse a peaceful student demonstration on the night of the 29th of November 2013 in Independence Square (Maidan) in Kyiv. On the morning of the 30th of November, initiators of the EuroMaidan SOS created a Facebook page and sent a post stating that they wanted to deal with cases of human rights violations by uniting voluntary efforts of lawyers, journalists, activists, and other concerned citizens. By the end of the day, the Facebook page was visited by about 10,000 users and the hotline numbers received around 300 calls from victims, witnesses, and professionals willing to help. After the end of the Revolution of Dignity, the initiative continues its function, using the same volunteer-based system. The volunteers work with human rights issues in the whole country (especially in the eastern part of the country).

Dyvovyzhni ("Wonderful") is another group of activists who promote, stimulate, and develop responsible citizens and communities in the postEuroMaidan society (@Dyvovyzhni). By involving local residents and doing simple fixes with them (e.g., painting old walls, planting flowers and trees, installing electricity-saving bulbs in the broken street lights), they inspire people to take responsibility in their own backyard, country, and planet. The idea behind the promotion of these small actions is to show tangible results that will enable participants to believe in the possibility of bigger actions, such as anticorruption or sustainable development actions.

The Reanimation Package of Reforms (RPR) is another initiative that emerged during EuroMaidan times. It started during an informal meeting of

\footnotetext{
5 However, this study is primarily exploratory in nature and does not aim to provide a representative comprehensive analyses of all the positions and actors involved in GIs in Ukraine. Rather, it attempts to pinpoint general trends in the selected examples.
} 
community activists, experts, journalists, and academics in a cafeteria during the protest period. Their work began by gathering reform legislation that had been developed, but not adopted, during the rule of Ianukovych. ${ }^{6}$ Importantly, during this critical period they began to work together to develop new legislation that would reflect the values and visions of the Revolution of Dignity. As a result, on March 7, 2014, they officially launched the organization "Reanimation Package of Reforms (RPR)" and continued the idea of citizens-created legislation. Due to their efforts and the continual pressure they placed on lawmakers, the group was able to push through truly revolutionary reform laws in critical areas, including anticorruption, public broadcasting, the judicial system, and higher education. For example, up to 80 laws developed by the RPR community are now adopted in the National Legislation.

OPIR.OGR (Opir) is yet another initiative that appeared during the Revolution of Dignity. At the beginning, young initiators of OPIR.ORG developed several applications that would, for example, improve safety of the protesters or allow mapping all social initiatives around the protest camp. After the end of the protest, they decided to focus on the issues of election transparency. They developed a new application and initiated a new social network. Their new application allows for quickly capturing violations during elections and sending an online video stream to the polling stations. Such violations can be monitored by every citizen who has access to the Internet.

Several "back-to-the-land" initiatives also originated during the EuroMaidan protests. Participants decided to "withdraw" from the busy reality of the current crisis and moved to rural areas. In their blog they invited other people to join them in creating an alternative sustainability village. Together they built a small community, where they now live a simple life in harmony with nature and each other, as they say. They build their own houses out of local resources, grow their own food, collect rain water, and develop their own solar collectors and small wind turbines while practising other aspects of an environmentally friendly lifestyle.

Heavenly Hundred Garden (HHG) is another example of environmentally focused initiatives. This urban garden is not as radical as the back-to-the-land examples; however, it also revitalizes the ideas of connecting back to "roots." Heavenly Hundred Garden is not just a common urban garden; it has a very strong symbolical meaning. Before EuroMaidan, the area HHG inhabits was a dump, surrounded by fences which the demonstrators used as shields during violent clashes with the police. Once the conflict was over, people with nothing other than their own hands and

\footnotetext{
${ }^{6}$ Viktor Ianukovych is a Ukrainian politician who served as the fourth President of Ukraine from February 2010 until his removal from power in February 2014.
} 
with no institutional support, decided to enter the dump, clean it, and turn it into a memorial garden for those who lost their lives during the Revolution of Dignity. The place turned out to be a space for community gardening, cultural events, as well as a citizens' meeting point, where they could share their worries and expectations as well as the city's development ideas.

Plushkin is an online network created by young activists who aimed to improve environmental and economic conditions in the country in 2014 (@Plushkin). The online network helps to decrease waste and consumption by allowing citizens to exchange goods among each other. Members can post an offer-an item that they no longer need-while other members can suggest an exchange. Members can contact each other directly on this platform and arrange a way to exchange goods-either by post or in person. A diverse range of items are exchanged in that way, including clothes, books, furniture, mobile phones, computers, and cars-just to give some examples. Now the platform offers a possibility to exchange not only materials but also services. For example, singing lessons can be exchanged for a dress or English lessons.

The online platform "Murahy" ("Ants") is another grassroots initiative project that allows for the sale of no longer needed items, while automatically redirecting the income to social initiatives (@Murahy). It was created in 2015 by EuroMaidan activists who were involved in resource generation during the protest period. They felt a responsibility to continue the idea of mutual help among people and created a platform that enables this mutual help. For example, a person from a rural area without a high income can place an advertisement to sell a few kilos of apples (that would spoil otherwise), while those with the opportunity to travel can pick up those apples. This transaction would be made without the physical exchange of money between seller and buyer; funds are paid by the buyer online and are automatically directed to social initiatives, while paying the corresponding taxes.

\section{RESULTS}

\subsection{ORGANIZATIONAL STRUCTURE}

All analyzed initiatives have different organizational structures and status. Among all of the initiatives, the back-to-the-land one is probably the least institutionalized; that is, they are not focused on gaining official status (according to the interviewees), while RPR is probably the most wellorganized and institutionalized. RPR is registered as an NGO and works as 
an umbrella and co-working space for hundreds of other organizations and experts (see Table 3).

Respondents from the initiative EuroMaidan SOS are also keen on keeping up the GI, without converting the group into a registered NGO. Another initiative, Heavenly Hundred Garden, also remains an initiative. At the same time, the steward of the HHG project is concerned with the legal status of the initiative. Participants in the GI fought for two years to protect this community garden from construction activities. Only in July 2016 did the city of Kyiv make a decision to protect the garden and stop the construction plans, in this way recognizing the HHG initiative.

Stewards of another initiative, OPIR.ORG, are working on converting the initiative "into a politically and financially independent NGO," as stated by the organizer. A similar story has been told by the activists from Dyvovyzhni. After a few years of grassroots volunteer-based activities, they decided to officially register the organization. The representative of the Dyvovyzhni project stated that the group is not aiming to change the range of activities and "does not want to lose the connection to grassroots; instead this transformation would help to expand the group to other regions of Ukraine, ${ }^{7}$ increase the size of activities, involve more people, and help in search for funds."

Similar stories were told by the respondents from Plushkin and Murahy initiatives. They started as small online groups but turned into officially registered organizations with thousands of users and followers: "it is important to be registered in order to be in the legal zone . . . but I don't want to be seen as one of these people working to get funds .... I am working in order to make a difference .... I want to be grassroots" was the comment made by the respondent from Murahy.

\subsection{INDIVIDUAL OR COMMON EFFORTS?}

Initiatives that were analyzed had different numbers of participants, members, and followers. For example, the social media page of EuroMaidan SOS has 123,803 followers (@EuroMaidan) and "hundreds of online and offline volunteers willing to co-operate," according to respondents (see Table 3). Although EuroMaidan SOS is not registered as an official NGO, $38 \%$ of Ukrainians know about EuroMaidan SOS and its functions ("Citizen's Awareness and Engagement of Civil Society). Another initiative, the Dyvovyzhni project, unites over 7,000 followers in social media

\footnotetext{
${ }^{7}$ In addition to Kyiv, GIs are currently being established in Dnipro and Kharkiv, and more establishments are planned. All translations of interviews are my own.
} 
(@Dyvovyzhni). A respondent commented that the Dyvovyzhni project "involves hundreds of people in the everyday citizenship activities (e.g., painting walls or cleaning parks)." OPIR and back-to-the-landers unite efforts of dozens of activists; OPIR has an extra 3000 followers in online networks (@Opir). Heavenly Hundred Garden has around 4000 followers on social media and hundreds of activists are involved (@HeavenlyHundredGarden). Plushkin has an online network of over 10,000 users, while Murahy unites the efforts of more than 4,000 users. Finally, RPR has a network that consists of over 100 different NGOs, hundreds of individual experts, and 33,741 followers on Facebook (RPR).

\subsection{TRUST}

Participants from all GIs declared low to moderate trust of government structures. "Of course, I don't trust the governmental structures ... they did not change much after the Revolution of Dignity ... people changed but the government did not," was the comment of a respondent from OPIR.ORG. "We see that the government is not capable of solving problems. But we as community can do it . . . and the Murahy platform allows people to solve their own problems, without going to the state or some foundations," was the comment of a respondent from Murahy (see Table 3). At the same time, all participants stressed a rising level of trust in other organizations, volunteers, and ordinary citizens. "I don't want to say anything about the state, but what I see and feel is that I can actually trust fellow citizens, all these volunteers, new organizations," was the comment of a respondent from the Dyvovyzhni project. Similar statements were made by respondents from all the initiatives, who mentioned trust of "fellow citizens," "volunteers," "civil initiatives," "active people," and "those who care."

\subsection{RoLE}

All the organizations' respondents were talking about different roles of their organizations in the development of civil society. Despite the diversity of views, it was possible to identify two main lines of argument. Many respondents stressed the need to create a new civic culture, while others focused more on the design of a new democracy.

For those who were focusing on a new civic culture, the role of civil society was seen in creating a new culture of dignity, referring to the Revolution of Dignity. In most of the cases they connected dignity with new 
socio-cultural, ecological, political, and economic (and thus, sustainable) behavioural rules/patterns in society. From a social perspective, these patterns would be based on active and responsible behaviour and are a part of "detoxication from the passive hangover of the past," according to respondents from Dyvovyzhni. From an economic perspective, some of the initiatives were questioning current neoliberal economic culture: "we want to bring back sanity into the harsh world of competition among money and politics ... to show existence of alternatives to current models of human existence," stated the respondent from Plushkin. "Our main idea is to integrate the culture of dignity and habit of not-only-for profit behaviour and community support into everyday habit," commented the respondent from Murahy. Finally, from the environmental dimension, initiatives were talking about nature-human interactions, as mentioned by the back-to-theland's respondent: "we are part of the nature and we need to reconnect to the roots and maybe this is the most important function of civil societynot only to connect with the government but also to connect with nature."

Many GIs participants were talking about a new democracy design. "Democracy is such an old concept; we need to think about new ways to implement it in modern educated societies," commented a respondent from OPIR.ORG. "By developing our IT tools, we enable citizens to be more than just passive voters. People are a real power and we decide our future-this is what we want to achieve with our activities," added the same respondent. Similar comments were made by respondents from Heavenly Hundred Garden, whose participants fought for two years against construction work in the territory of the garden to prove that "people are the power and can decide what they want to see in their city." The interviewees from RPR were sceptical regarding creating a new form of democracy; instead they focus on "making the voice of people and civil society stronger" in the current democratic system. The respondent from EuroMaidan SOS focused on the watchdog function of the civil society. "Even when we will have a good power, we would have to be prepared .... we need a strong civil society so that you do not wake up one day and one dictator is in charge of your country and you don't know what to do," she commented. 
Table 3. Characteristics of the Analyzed GIs: Part I

\begin{tabular}{|c|c|c|c|c|}
\hline & EuroMaidan SOS & Wonderful & Plushkin & Murahy \\
\hline Role & Watchdog & New culture & New culture & New culture \\
\hline Trust & $\begin{array}{l}\text { Other } \\
\text { organizations and } \\
\text { people }\end{array}$ & $\begin{array}{l}\text { Other } \\
\text { organizations } \\
\text { and people }\end{array}$ & $\begin{array}{l}\text { Other } \\
\text { organizations } \\
\text { and people }\end{array}$ & $\begin{array}{l}\text { Other } \\
\text { organizations } \\
\text { and people }\end{array}$ \\
\hline Organization & Not registered & $\begin{array}{l}\text { In the process to } \\
\text { register }\end{array}$ & Registered & Registered \\
\hline $\begin{array}{l}\text { Individual } \\
\text { efforts }\end{array}$ & $\begin{array}{l}\text { Network of over } \\
100 \text { lawyers and } \\
123,803 \text { online } \\
\text { members }\end{array}$ & $\begin{array}{l}\text { Network of over } \\
7,000 \text { online } \\
\text { members. }\end{array}$ & $\begin{array}{l}\text { Network of over } \\
10,000 \text { users }\end{array}$ & $\begin{array}{l}\text { Network of } \\
\text { over } 4000 \\
\text { users }\end{array}$ \\
\hline
\end{tabular}

Table 3. Characteristics of the Analyzed GIs: Part II

\begin{tabular}{|c|c|c|c|c|}
\hline & $\begin{array}{l}\text { Back-to-the- } \\
\text { Landers }\end{array}$ & RPR & OPIR & $\begin{array}{l}\text { Heavenly } \\
\text { Hundred } \\
\text { Garden }\end{array}$ \\
\hline \multirow[t]{2}{*}{ Role } & New culture & $\begin{array}{l}\text { Bridging people } \\
\text { and state }\end{array}$ & $\begin{array}{l}\text { New } \\
\text { democracy }\end{array}$ & $\begin{array}{l}\text { New } \\
\text { democracy }\end{array}$ \\
\hline & & & Watchdog & New culture \\
\hline Trust & $\begin{array}{l}\text { Other } \\
\text { organizations and } \\
\text { people }\end{array}$ & $\begin{array}{l}\text { Other } \\
\text { organizations and } \\
\text { people }\end{array}$ & $\begin{array}{l}\text { Other } \\
\text { organizations } \\
\text { and people }\end{array}$ & $\begin{array}{l}\text { Other } \\
\text { organizations } \\
\text { and people }\end{array}$ \\
\hline Organization & Not registered & Registered & $\begin{array}{l}\text { In the process } \\
\text { of registering }\end{array}$ & Registered \\
\hline $\begin{array}{l}\text { Individual } \\
\text { efforts }\end{array}$ & $\begin{array}{l}\text { Small offline } \\
\text { network }\end{array}$ & $\begin{array}{l}\text { Network of } 100 \\
\text { organizations and } \\
\text { thousands of } \\
\text { individuals }\end{array}$ & $\begin{array}{l}\text { Small } \\
\text { network of } \\
\text { over } 3000 \\
\text { online } \\
\text { members }\end{array}$ & $\begin{array}{l}\text { Network of } \\
\text { over } 4000 \\
\text { online } \\
\text { followers }\end{array}$ \\
\hline
\end{tabular}

\section{DISCUSSION}

The described cases of civil engagement in Ukraine represent a wide variety of organizational structures starting from occupied urban spaces (e.g., Heavenly Hundred Garden) to umbrella organizations uniting hundreds of registered NGOs and experts (such as RPR). Some of the organizations have a clear management structure, while others are more informal gatherings; some rely heavily on new technologies (like OPIR), while others rely on human-to-human interactions (back-to-the-land initiatives); some are registered organizations, while others are small civil initiatives. Thus forms of civil engagement in Ukraine are diverse and for 
this reason might be seen as "uncivil" to researchers' eyes (e.g., D'Alisa et al.).

At the same time, it is difficult to deny the existence of civil activation in Ukrainian society. Moreover, it is problematic to explain such activation by citing individual efforts, for example, as in the publication by Cleary that discusses the work of individual volunteers. This study has shown that some GIs have over 10,000 users-like Plushkin or RPR which have networks of over 100 registered organizations. The individual and unorganized efforts of volunteers contradict the argument that Ukrainian civil society has weak and/or pseudo-plenipotentiary vision.

A second argument for pseudo-plenipotentiary vision is that the emerging initiatives are not able to establish mechanisms to control or influence power. This study, however, showed several examples of initiatives that are specifically working to form a bridge between civil society and power. RPR, for example, unites more than 100 different NGOs and experts, who lobby together for regulations developed by them. As a result, more than 80 laws developed by RPR have been adopted in the national legislation. At the same time, young Ukrainian entrepreneurs are developing IT tools for better civil control of power. The OPIR application that enables everyone to be an observer during elections is just one example.

Cleary and Caldwell do have a point when they state that civil society in Eastern Europe might assume a "wrong" role of "helping" or performing the function of the state. Such a point might be seen in examples of Ukrainian social initiatives whose members attempt to help injured soldiers or even perform security functions by volunteering in battalions in the eastern parts of the country. But the wider picture of different civil initiatives, e.g., developing city gardens (such as Heavenly Hundred Garden), exchanging platforms to create market economy alternatives (e.g., Plushkin, Murahy), or trying to "energize" civil society (e.g., Dyvovyzhni), goes beyond simply fulfilling the role of the state. Moreover, participants in the analyzed GIs are trying to act without a state or despite the state. This is very different from the idea of helping the state. This desire to act without a state or to strive toward autonomy and self-reliance can be explained by the low level of trust in state institutions.

Given this background, I would agree with Cleary that "if one of the hallmarks of civil society is the development of communities of trust between society and government structures, then Ukraine's civil society has a long way to go" (17). But if we look at the number of blooming diverse grassroots initiatives, and more importantly the trust inside civil society, the view is very different. In addition to the results of this empirical study, a recent poll showed that among all public and power institutions, citizens of Ukraine trust volunteers the most $(67 \%)$, followed by civil 
organizations (13\%) ("Komu bil'she doviriaiut' ukraintsi"). This is very different from previous results of mistrust of civil society actors in, for instance, 2012 as described by Pytlik (250). Can this type of trust be a hallmark of a strong civil society? This question needs more in-depth investigation.

In any case, these observations confirm Newton's ideas about the complex relationship between political trust and civil society. Similar to his results, the analyzed cases of GIs show that social trust between citizens is not always related to trust between citizens and political leaders (Newton). Distrust of government can be a legitimate choice of citizens, whereas a large number of official NGOs might not be a product of a weak society or defective democracy, similar to what Whittington and Petrova and Tarrow have shown.

Thus, let's come back now to the question of Cleary: "If civil society is not able to bridge the gap between the people and the government then what is it doing?" (17). Instead of looking at the surveys and registered statistics, this study asked the participants about the role of these initiatives. The results were as diverse as the initiatives themselves, often going beyond the traditional Robert Putnam vision of society. However, in a very general sense, respondents were talking about the creation of a new civil culture and a new democracy. Those who were talking about a new culture very often mentioned a new culture of "dignity," referring to the connection with the Revolution of Dignity. From a social perspective, such a culture would mean "detoxication from the passive hangover of the past," and a transition toward a responsible and active society. From an economic perspective, it would mean developing alternative mechanisms of nonmarket interactions and questioning current neoliberal economic culture. Finally, from an environmental perspective, the GI culture can be seen as an attempt to care more for nature-human interactions.

Other initiatives were experimenting with a new or improved democracy design. "Democracy is such an old concept, we need to think about new ways to implement it in modern educated societies," was a comment provided by a respondent from OPIR.ORG. Many are working as watchdogs in this "new democracy" society.

In general, the examples show that actors, roles, and forms of contemporary civic engagement in Ukraine are diverse and can be unconventional or non-institutionalized. This study not only questioned the weak or pseudo-plenipotentiary vision of civil society in Ukraine but also challenged the traditional view of what constitutes a civil society. As such, it contributes to the "many civil societies" theoretical arguments of Edwards and Foley. More importantly, I added empirical examples from Eastern Europe to the collection of diverse forms of civil activation described by, e.g., Jacobsson and D'Alisa and others. 


\section{CONCLUSION}

Post-revolutionary Ukrainian society has undergone tremendous changes over the past decades: from a state-controlled associational life, to a Western-sponsored civil society, to today's diverse civil life. These changes were grassroots driven, were developed in response to local problems and needs, and were inspired by global sustainability concerns.

Ukraine displays a unique mix of enthusiasm, creativity, conflict trauma, radicalism, and disappointment with the state. It is possible to describe this society in many different ways, but not as weak. Hence, examples of new civil societies from Ukraine challenge the traditional view of what constitutes the actors and roles of civil society and at the same time provides inspiring ideas for social, political, environmental, and economic sustainable development. These new approaches, in spite of their limits, can be sources of inspiration for the new sustainable society paradigm. The future, however, will tell if these approaches advance or disappear in economic and political crises.

\section{Works Cited}

Bernhagen, Patrick, and Michael Marsh. "Voting and Protesting: Explaining Citizen Participation in Old and New European Democracies." Democratization, vol. 14, no. 1, 2007, pp. 44-72. Crossref, doi: 10.1080/13510340601024298.

Bohdanova, Tetyana. “Unexpected Revolution: The Role of Social Media in Ukraine's Euromaidan Uprising." European View, vol. 13, no. 1, 2014, pp. 133-42. Crossref, doi:10.1007/s12290-014-0296-4.

Burford, Gemma, et al. "Bringing the 'Missing Pillar' into Sustainable Development Goals: Towards Intersubjective Values-Based Indicators.” Sustainability, vol. 5, no. 7, 2013, pp. 3035-59. Crossref, doi: 10.3390/su5073035.

Caldwell, Melissa L. "Placing Faith in Development: How Moscow's Religious Communities Contribute to a More Civil Society." Slavic Review, vol. 71, no. 2, 2012, pp. 261-87. Crossref, doi: 10.5612/slavicreview.71.2.0261.

Castells, Manuel, et al. Aftermath: The Cultures of the Economic Crisis. Oxford UP, 2012.

Chandhoke, Neera. "The 'Civil' and the 'Political' in Civil Society." Democratization, vol. 8, no. 2, 2001, pp. 1-24. Crossref, doi: 10.1080/714000194.

"Citizen's Awareness and Engagement of Civil Society: Results of Research Conducted During November 2015-January 2016." GfK, 2016. http://www.gfk.com/fileadmin/user_upload/dyna content/UA/2 news2016/TK_final_Presentation_for_web-site_March_30.pdf. Accessed 15 May 2016.

Cleary, Laura. "Half Measures and Incomplete Reforms: The Breeding Ground for a Hybrid Civil Society in Ukraine." Southeast European and Black Sea Studies, vol. 16, no. 1, 2016, pp. 7-23. Crossref, doi: 10.1080/14683857.2016.1148410. 
D'Alisa, Giacomo, et al. "Civil and Uncivil Actors for a Degrowth Society." Journal of Civil Society, vol. 9, no. 2, 2013, pp. 212-24. Crossref, doi: 10.1080/17448689.2013.788935.

“Dumky ta pohliady naselennia Ukrainy: liutyi 2012 (OMNIBUS KMIS 2012/02).” National'nyi bank doslidzhen', 2014. http://ukraine.surveyarchive.com/data\#user-research@showResearch=116945. Accessed 16 Apr. 2016.

@Dyvovyzhni. Facebook, https://www.facebook.com/dyvovyzhni/?fref=ts. Accessed 27 Nov. 2015.

Edwards, Bob, and Michael W. Foley. "Civil Society and Social Capital Beyond Putnam." American Behavioral Scientist, vol. 42, no. 1, 1998, pp. 124-39. Crossref, doi: 10.1177/0002764298042001010.

Ekman, Joakim, et al. "Challenges and Realities of Political Participation and Civic Engagement in Central and Eastern Europe." East European Politics, vol. 32, no. 1, 2016, pp. 1-11. Crossref, doi: 10.1080/21599165.2016.1141091.

@EuroMaidanSOS. Facebook, https://www.facebook.com/EvromaidanSOS/. Accessed 11 Oct. 2015.

Fukuyama, Francis. "Social Capital, Civil Society and Development." Third World Quarterly, vol. 22, no. 1, 2001, pp. 7-20. Crossref, doi: 10.1080/713701144.

Gatskova, Ksenia, and Maxim Gatskov. The Weakness of Civil Society in Ukraine: A Mechanism-Based Explanation. IOS Working Papers, no. 323, 2012. http://www.dokumente.ios-regensburg.de/publikationen/wp/wp_ios_323.pdf. Accessed 13 Oct. 2016.

---. "Third Sector in Ukraine: Civic Engagement Before and After the 'Euromaidan."' VOLUNTAS: International Journal of Voluntary and Nonprofit Organizations, vol. 27, no. 2, Apr. 2016, pp. 673-94. Crossref, doi: 10.1007/s11266-015-9626-7.

Gorobets, Alexander. "An Independent Ukraine: Sustainable or Unsustainable Development?" Communist and Post-Communist Studies, vol. 41, no. 1, 2008, pp. 93-103. Crossref, doi: 10.1016/j.postcomstud.2007.12.002.

Gramsci, Antonio. Further Selections from the Prison Notebooks. U of Minnesota P, 1995.

@HeavenlyHundredGarden. Facebook, www.facebook.com/Місто-сад596897543717942/. Accessed 13 Nov. 2015.

Hemment, Julie. "Soviet-Style Neoliberalism? Nashi, Youth Voluntarism, and the Restructuring of Social Welfare in Russia." Problems of Post-Communism, vol. 56, no. 6, 2009, pp. 36-50. Crossref, doi: 10.2753/PPC1075-8216560604.

Howard, Marc Morjé. The Weakness of Civil Society in Post-Communist Europe. Cambridge UP, 2003.

"Komu bil'she doviriaiut' ukraintsi: vladi, hromads'kosti, ZMI..?." Fond Demokratychni initsiatyvy imeni Il'ka Kucheriva, 2015. http://dif.org.ua/article/komu-bilshe-doviryayut-ukraintsi-vladi-gromadskostizmi. Accessed 12 July 2016.

Iedynyi reiestr hromads'kykh formuvan'. http://rgf.informjust.ua/. Accessed 11 May 2016.

Indicators of Sustainable Development: Framework and Methodologies. UN Department of Economic and Social Affairs, Division for Sustainable 
Development, 2001. http://www.un.org/esa/sustdev/csd/csd9_indi_bp3.pdf. Accessed 8 Feb. 2016.

Jacobsson, Kerstin. Urban Grassroots Movements in Central and Eastern Europe. Ashgate Publishing, 2015.

Kingsley, Jonathan, and Mardie Townsend. "Dig In' to Social Capital: Community Gardens As Mechanisms for Growing Urban Social Connectedness." Urban Policy and Research, vol. 24, no. 4, 2006, pp. 525-37. Crossref, doi: 10.1080/08111140601035200.

Kopecký, Petr, and Cas Mudde. "Rethinking Civil Society." Democratization, vol. 10, no. 3, 2003, pp. 1-14. Crossref, doi: 10.1080/13510340312331293907.

Kostelka, Filip. "The State of Political Participation in Post-Communist Democracies: Low but Surprisingly Little Biased Citizen Engagement." Europe-Asia Studies, vol. 66, no. 6, 2014, pp. 945-68. Crossref, doi: 10.1080/09668136.2014.905386.

Levada, Iu., and A. Golov. Sovetskii prostoi chelovek: Opyt sotsial'nogo portreta na rubezhe 90-kh. "Mirovoi okean," 1993.

Ljubownikow, Sergej, et al. "The State and Civil Society in Post-Soviet Russia: The Development of a Russian-Style Civil Society." Progress in Development Studies, vol. 13, no. 2, 2013, pp. 153-66. Crossref, doi: 10.1177/1464993412466507.

"Molod' Ukrainy 2015." GfK Ukraine, 2015. https://www.gfk.com/fileadmin/user upload/dyna content/UA/Molod Ukrain e 2015 UA.pdf. Accessed 3 Mar. 2016.

@Murahy. Facebook, https://www.facebook.com/murahy/. Accessed 13 Nov. 2015. Newton, Kenneth. "Trust, Social Capital, Civil Society, and Democracy." International Political Science Review, vol. 22, no. 2, 2001, pp. 201-14. http://www.jstor.org/stable/1601186. Accessed 18 Apr. 2016.

Ogryzko, Olesia, and Kateryna Pishchikova. Civic Awakening: The Impact of Euromaidan on Ukraine's Politics and Society. Fride: Working Paper, no. 124, July 2014. http://fride.org/descarga/WP 124_Civic awakening.pdf. Accessed 18 Apr. 2016.

@OPIR.ORG (@Opir).Facebook, https://www.facebook.com/opir.org. Accessed 27 Nov. 2015.

Palyvoda, Lyubov. Civil Society Organizations in Ukraine: The State and Dymanics (2002-2013). Creative Center Charitable Foundation, 2014. http://ccctck.org.ua/eng/download/library/56/. Accessed 10 Mar. 2016.

Pearson, Leonie J., et al. "Sustainable Urban Agriculture: Stocktake and Opportunities." International Journal of Agricultural Sustainability, vol. 8, no. 1-2, 2010, pp. 7-19. Crossref, doi: 10.3763/ijas.2009.0468.

Petrova, Tsveta, and Sidney Tarrow. "Transactional and Participatory Activism in the Emerging European Polity: The Puzzle of East-Central Europe." Comparative Political Studies, vol. 40, no. 1, 2007, pp. 74-94. Crossref, doi: 10.1177/0010414006291189.

Pfahl, Stefanie. "Institutional Sustainability." International Journal of Sustainable Development, vol. 8, no. 1-2, 2005, pp. 80-96. Crossref, doi: 10.1504/IJSD.2005.007376.

@Plushkin. Facebook, https://www.facebook.com/plushkin.obmen/. Accessed 13 Nov. 2015. 
Polanska, Dominika V. "Polish Civil Society in Bloom." Baltic Rim Economies, vol. 5, 2015, p. $42 . \quad \underline{\text { http://sh.diva- }}$ portal.org/smash/get/diva2:885828/FULLTEXT01.pdf. Accessed 7 Apr. 2016

Puglisi, Rosaria. A People's Army: Civil Society As a Security Actor in Post-Maidan Ukraine. Istituto Affari Internazionali Working Papers, 15-23 July 2015. http://www.iai.it/sites/default/files/iaiwp1523.pdf. Accessed 7 Apr. 2016.

Putnam, Robert D. “Bowling Alone: America's Declining Social Capital." Journal of Democracy, vol. 6, no. 1, 1995, pp. 65-78. http://xroads.virginia.edu/ hyper/detoc/assoc/bowling.html. Accessed 7 May 2016.

Pytlik, Kamila. "The Characteristics of the Third Sector in Ukraine. Increases and Decreases in the Activity of Particular Organizations and the Policy of the Ruling Elite." The Journal of Education Culture and Society, vol. 1, 2015, pp. 245-56. Crossref, doi: 10.15503/jecs20151.245.256.

Report of the World Commission on Environment and Development: Our Common Future. WCED, 1987. http://www.un-documents.net/our-common-future.pdf. Accessed 19 Jan. 2016.

RPR (Reanimation Package of Reforms). http://rpr.org.ua/en/. Accessed 13 Nov. 2015.

Sava, Ionel N. "A Second Generation of Grassroots Movements in Central and Eastern Europe?" Open Democracy / ISA RC-47: Open Movements, 11 May 2015. https://opendemocracy.net/ionel-n-sava/second-generation-of-grassrootsmovements-in-central-and-eastern-europe. Accessed 8 Feb. 2016.

Seyfang, Gill, and Noel Longhurst. "Desperately Seeking Niches: Grassroots Innovations and Niche Development in the Community Currency Field." Global Environmental Change, vol. 23, no. 5, 2013, pp. 881-91. Crossref, doi: 10.1016/j.gloenvcha.2013.02.007.

---. "What Influences the Diffusion of Grassroots Innovations for Sustainability? Investigating Community Currency Niches." Technology Analysis \& Strategic Management, vol. 28, no. 1, 2016, pp. 1-23. Crossref, doi: 10.1080/09537325.2015.1063603.

Seyfang, Gill, and Adrian Smith. "Grassroots Innovations for Sustainable Development: Towards a New Research and Policy Agenda." Environmental Politics, vol. 16, no. 4, 2007, pp. 584-603. Crossref, doi: 10.1080/09644010701419121.

Shiller, Robert J., et al. "Hunting for Homo Sovieticus: Situational Versus Attitudinal Factors in Economic Behavior." Brookings Papers on Economic Activity, vol. 1, 1992, pp. 127-94. Crossref, doi: 10.2307/2534558.

Smith, Adrian, et al. "Innovation Studies and Sustainability Transitions: The Allure of the Multi-Level Perspective and Its Challenges." Research Policy, vol. 39, no. 4, 2010, pp. 435-48. Crossref, doi: 10.1016/j.respol.2010.01.023.

"Sotsiolohichne opytuvannia: Chy doviriaiete Vy hromads'kym orhanizatsiiam? (dynamika, 2001-2013)." Tsentr 2013. http://old.razumkov.org.ua/ukr/poll.php?poll_id=81. Accessed 7 Apr. 2016.

"Sustainable Development Indicators and National Accounts." European Commission EUROSTAT, 2003. 
https://www.insee.fr/fr/statistiques/fichier/2586367/ravets.pdf. Accessed 4 July 2017.

“The 2015 CSO Sustainability Index for Central and Eastern Europe and Eurasia." USAID, 2015.

https://www.usaid.gov/sites/default/files/documents/1861/Europe Eurasia CSOSIReport_2015_Update8-29-16.pdf. Accessed 1 May 2016.

Thematic Report: Civil Society and Crisis in Ukraine. OSCE, 11 Feb. 2015. http://www.osce.org/ukraine-smm/141046?download=true. Accessed 19 Apr. 2016.

Verdery, Katherine. What Was Socialism, and What Comes Next? Princeton UP, 1996.

"Volonters'kyi rukh v Ukraini." GfK Ukraine, 2014. http://de.slideshare.net/two_day/survey-results-2014. Accessed 10 Apr. 2016.

Whittington, Keith E. "Revisiting Tocqueville's America Society, Politics, and Association in the Nineteenth Century." American Behavioral Scientist, vol. 42, no. 1, 1998, pp. 21-32. Crossref, doi: 10.1177/0002764298042001003.

Williams, Colin C., et al. "Bridges into Work? An Evaluation of Local Exchange and Trading Schemes (LETS)." Policy Studies, vol. 22, no. 2, 2001, pp. 119-32. Crossref, doi: 10.1080/01442870127252.

Załęski, Paweł Stefan. Neoliberalizm i społeczeństwo obywatelskie. Wydawnictwo Naukowe Uniwersytetu Mikołaja Kopernika, 2012. 